\title{
Gestational Choriocarcinoma
}

National Cancer Institute

\section{Source}

National Cancer Institute. Gestational Choriocarcinoma. NCI Thesaurus. Code C4646.

A rare, highly malignant epithelial tumor that develops from a hydatidiform mole (50\%), following abortion (25\%), or during normal pregnancy (22\%). It is characterized by the presence of invasive and anaplastic trophoblastic tissue composed of intermediate trophoblastic cells, cytotrophoblasts and syncytiotrophoblasts, abundant vascularity, and secretion of human chorionic gonadotropin. Because of rapid growth and a high propensity for hemorrhage, this neoplasm often constitutes a medical emergency. 